\title{
Pollution Control and Productivity Growth: Some Unusual Evidence from the U.S. Steel Industry
}

\author{
H. Youn Kim*
}

Department of Economics, Western Kentucky University, Bowling Green, KY 42101, U.S.A.

\begin{abstract}
This paper studies productivity growth in the U.S. steel industry using an early data set, 1957-76, and uncovers new evidence on the effects of pollution control. The model identifies the components of productivity growth with scale effects, pollution control, $R \& D$, and technical change, with allowance for markup behavior. There is evidence that $R \& D$ funds were diverted into pollution abatement, and $R \& D$ stock had a negative impact on productivity growth. While pollution control had a dampening effect on productivity growth in the early years of the period, compliance with stricter pollution laws in the later years provided an added incentive for modernization, which yielded an acceleration of productivity growth. This result is in sharp contrast to existing findings that support the negative view of pollution control on productivity growth.
\end{abstract}

Key words: Pollution control, Technical change, Total productivity growth, Translog Cost function, Scale economies. JEL Classification Numbers: D21, D24, L11, L69, Q52.

\section{INTRODUCTION}

Productivity is an important measure of efficiency, and identifying the sources of productivity growth has been a key issue in economic research. Many sources underlying productivity growth are identified and studied for firms, industries, and countries (see Syverson, 2011, for an excellent survey). Among them, it is widely held that pollution control has a deleterious effect on measured productivity growth because productive inputs are diverted from primary production to pollution abatement. Pollution control may also have the impact of diverting funds from R\&D on primary production technologies and may slow the rate of productivity growth. There is abundant evidence linking the productivity slowdown to various pollution control programs in various industries (see, e.g., Crandall, 1981b; Gollop and Roberts, 1983; Smith and Sims, 1985; Barbera and McConnell, 1986; Conrad and Morrison, 1989; Färe et al., 1989; Aiken and Pasurka, 2003; Zivin and Neidell, 2012; see Christainsen and Haveman, 1981 for a survey).

This study reexamines the pollution control - productivity nexus and uncovers new evidence from a collection of a unique data set for the U.S. steel industry in the early period, 1957-76. In order to properly understand the productivity impact of pollution control, it is important to allow for the relationships that lie among pollution control, $\mathrm{R} \& \mathrm{D}$, and technical change. Previous studies relating pollution control to productivity have not considered $\mathrm{R} \& \mathrm{D}$ as a potent variable (Crandall, 1981b; Gollop and Roberts, 1983; Smith and Sims, 1985; Conrad and Morrison, 1989; Färe et al., 1989;

\footnotetext{
*Address correspondence to this author at Department of Economics, Western Kentucky University, Bowling Green, KY 42101, U.S.A.,

E-mail: youn.kim@wku.edu
}

Aiken and Pasurka, 2003). On the other hand, studies examining the effect of $R \& D$ on output or productivity have excluded the pollution control variable (Griliches, 1988; Nadiri and Schankerman, 1981a; Mansfield, 1981). However, changes in pollution control have no independent and separate effect on productivity growth. Rather, they may alter the firm's R\&D activities and determine the direction and rate of technological innovation (Eads, 1980), which in turn affect productivity growth. Previous analyses of productivity have not isolated the pollution effect from R\&D and/or technical change effects, and thus the productivity effect of pollution control is confounded with those of R\&D and/or technical change. Only by isolating pollution control, $\mathrm{R} \& \mathrm{D}$, and technical change effects, can we get a full montage of how changes in pollution control affect productivity.

Steelmaking generates a substantial amount of pollution, and there are stringent environmental regulations on pollution imposed on the U.S. steel industry, which impinges on productivity growth. The industry has undergone a significant transformation in production technology. However, the major breakthrough in steelmaking technology took place in the mid 1950's with the introduction of the basic oxygen furnace (BOF) (Sumrall, 1982; Oster, 1982). This technology has been the dominant technology employed in the U.S. steel industry over the years. We use an early data set to trace the effect of the BOF technology on productivity growth in relation to pollution control subsequent to its introduction in the U.S. steel industry. The data set contains the actual technology adoption rate that was taking place in the steel industry, which can be used as a direct measure of technical change. Previous studies on productivity specify the rate of technical change as a function of time (see, e.g., Diewert and Fox, 2008), but time may act as a proxy for all the other unknown variables. While there are several studies 
estimating the production or cost function of the steel industry (Kopp and Smith, 1981; Oster, 1982; Karlson, 1983; Lieberman and Johnson, 1999; Collard-Wexler and De Loecker, 2015), they are largely concerned with input substitution and scale economies with no regard to pollution, $\mathrm{R} \& \mathrm{D}$, and technical change in their analyses.

The underlying framework for this paper is a full model of steel production based on profit maximization characterized with a translog cost function, which allows us to identify the components of total productivity growth associated with scale effects, pollution control, R\&D, and technical change, with allowance for markup behavior. The presence of pollution control requires a modification of the conventional measure of scale economies (Chambers, 1988; Diewert and Fox, 2008). Also, the fact that the steel industry is imperfectly competitive requires an adjustment of the conventional productivity measure based on competitive marginal cost pricing with constant returns to scale (Chambers, 1988). Moreover, previous analyses are based on many restrictive assumptions on the steel production structure, and various restrictive hypotheses maintained in these analyses, especially with respect to pollution control, are examined and tested.

The U.S. steel industry underwent a sharp decline in productivity growth in the $1957-76$ period. ${ }^{1}$ The decline in the demand for domestic steel and slowness to adopt new technologies were largely responsible for the productivity slowdown. Steel imports did not always have a detrimental effect on productivity growth. There is clear evidence that R\&D funds were diverted to pollution abatement, and R\&D stock in general had a negative effect on productivity growth. Pollution control was not an entirely detrimental influence on productivity growth during the study period. While pollution control had a dampening effect on productivity growth in the early years of this period, compliance with more stringent pollution standards in the later years of the period appears to have provided an added incentive to the steel industry for modernization, which yielded an acceleration of productivity growth. These results are illuminating and in sharp contrast to existing findings that support the negative view of pollution control on productivity growth.

\section{THE ANALYTICAL FRAMEWORK}

This section presents a theoretical framework for analyzing pollution control and its impact on productivity growth, which will form an appropriate base for subsequent empirical analysis.

\section{Market Production of Steel and Pollution}

Suppose the steel industry faces a cost function of the form:

$C=C(Y, A, \mathbf{w}, R, T)$,

where $\mathrm{Y}$ is steel output, $\mathrm{A}$ is the amount of pollution abatement, $\mathbf{w}$ is the price vector of inputs whose elements are $w_{i}$

1 Collard-Wexler and De Loecker (2015) provide a god discussion of the U.S. steel industry in recent years, and use more recent data and examine the link between technical change and productivity. They do not consider the effects of pollution control and R\&D. See Section $V$ for a relevant discussion of their study relative to this study. $(\mathrm{i}=1, \ldots, \mathrm{n}), \mathrm{R}$ is the stock of $\mathrm{R} \& \mathrm{D}, \mathrm{T}$ is the level of technology determined by technical change ${ }^{2}$, and $C=\sum_{i=1}^{n} w_{i} x_{i}$, total expenditure on inputs, where $x_{i}$ is the quantity of the ith $(i=1, \ldots, n)$ input. Four aggregate inputs are considered in steel production: capital $(\mathrm{K})$, labor $(\mathrm{L})$, energy (E), and raw materials (M). There are several steelmaking technologies such as the basic oxygen, open hearth, and electric arc furnace processes. ${ }^{3}$ However, it is generally accepted that the introduction of the basic oxygen furnace (BOF) technology in the mid 1950's represents "the only major technological breakthrough at the ingot level in the steel industry since before the turn of century" by replacing the open hearth furnace (Sumrall, 1982; Oster, 1982). While there has been a gradual increase in steel production or shipment by the use of the electric arc furnace, the BOF technology has been the dominant technology in the U.S. steel industry (Collard-Wexler and De Loecker, 2015; see a more discussion in Section V). For this reason, we focus on the BOF technology and examine the effect on steelmaking subsequent to its introduction in the U.S. steel industry. Technical change is measured by the BOF adoption rate as given by the fraction of steel output produced with the BOF technology.

The cost function (1) is assumed to be increasing, linear homogeneous, and concave with respect to input prices, and increasing in output (Chambers, 1988). Assuming that input markets are competitive with the input prices determined exogenously, ${ }^{4}$ Shephard's lemma applied to the cost function (1) gives the input demand functions:

$\frac{\partial C}{\partial w_{i}}=x_{i}(Y, A, \mathbf{w}, R, T), i=1, \ldots, n$

Steel is a marketable output. Pollution, considered a nonmarketable, undesirable output ("bad"), is a byproduct of the steel production process. ${ }^{5}$ Pollution regulations require abatement or cleanup of pollutants. It is assumed that pollution is weakly disposable (Färe et al., 1989), so that a reduction in pollution can be only achieved by simultaneously reducing steel production. The tradeoff between steel production and pollution abatement is given by

2 To a certain degree, both R\&D and the BOF adoption rate measure technical change (Teleckyj, 1980). R \& D is an input measure, while the $\mathrm{BOF}$ adoption rate is an output measure of technical change. In reality, however, both variables are imperfect measures of true technical change, and hence the two variables are included in the cost function. This is a common specification adopted in the study of the R \& D effect on output and productivity (see Griliches, 1988; Nadiri and Schankerman, 1981a, b). 3 A detailed discussion of the steel production process is given in Kopp and Smith (1981); see also Crandall (1981a), Oster (1982), and Collard-Wexler and De Loecker (2015).

4 See Grossman (1986) for a detailed discussion of exogeneity of input prices in the steel industry.

5 It would also be possible to model pollution or pollution abatement as a direct input in the production process by separating the pollution abatement capital from total capital input (Kopp and Smith, 1981; Conrad and Morrison, 1989). However, the output framework is intuitively more appealing (see Pittman, 1981; Färe et al., 1989). 
$\frac{d Y}{d A}=-\frac{\partial C / \partial A}{\partial C / \partial Y}$

Additional production of steel requires expenditure on inputs, so that $\partial C / \partial Y>0$. However, reducing pollution, i.e., increasing pollution abatement, increases the cost of steel production at least over some range because of the diversion of inputs from steel production to pollution abatement, implying that $\partial C / \partial A>0$. This determines the negative tradeoff between steel production and pollution abatement for a given level of inputs, i.e., $d Y / d A<0$ implying a positive opportunity cost for reducing pollution in terms of forgone steel output.

The rate of tradeoff between steel output and pollution abatement depends on input substitution possibilities associated with the diversion of inputs due to pollution abatement. If inputs have no substitution possibilities, steel output would be crowded out by an increase in pollution abatement on a one-to-one basis, i.e., $|d Y / d A|=1$. If input substitution is feasible, pollution abatement expenditures do not divert equivalent expenditures on inputs and output would not fall by the increase in pollution abatement, i.e., $|d Y / d A|<1$. This tradeoff relation is, however, static in nature and does not take into account the dynamic adjustment process induced by pollution control. In particular, to the extent that stringent pollution standards entail technological innovation, which increases production efficiency from adopting a new technology, this regulation-induced technical change will bring about a reduction in costs, i.e., $\partial C / \partial A<0$ hence we cannot rule out the possibility that $d Y / d A>0$ implying a negative marginal value of pollution abatement in terms of foregone steel output. An important part of this study is to determine empirically the tradeoff between steel output and pollution abatement.

The output of steel is sold under conditions of imperfect competition, so that its price $\mathrm{p}$ is a function of the level of output. The amount of pollution abatement is determined by market considerations subject to a lower limit on pollution abatement $A^{\mathrm{o}}$ to comply with the mandated regulation. The profit-maximizing steel firm must choose output and pollution abatement levels to maximize profit subject to the production technology represented by the cost function (1) and to the pollution abatement constraint. The firm's objective is then:

$\max _{Y,{ }_{A}}\{p(Y) Y-C(Y, A, \mathbf{w}, R, T)\}$

s.t. $A \geq A^{\circ}$

Profits are maximized when the following first-order conditions hold:

$p\left(1+\frac{1}{\eta}\right)=\frac{\partial C}{\partial Y}$

and

$\lambda=\frac{\partial C}{\partial A}$ for $\lambda>0$ where $\eta$ is the price elasticity of the demand for steel and $\lambda$ is the Lagrange multiplier associated with the pollution abatement constraint, which represents the shadow price or opportunity cost of complying with pollution control regulation. ${ }^{6}$ Equation (5) is the standard profit-maximizing $\mathrm{MR}=\mathrm{MC}$ condition. Equation (6) shows that if pollution regulation is binding (i.e., $A<A^{\circ}$ ), then $\lambda>0$ and the opportunity cost of compliance with pollution regulation is the marginal abatement cost of pollution. If, however, pollution control is not binding (i.e., $A \geq A^{\circ}$ ), then the opportunity cost of pollution control would be zero (i.e., $\lambda=0$ ). In addition, with the appropriate second-order condition for profit maximization met, the optimal output level is implicitly determined from (5). Substituting it into (2), we obtain the optimal input quantities.

\section{Adjusting the Degree of Scale Economies for Pollution Abatement}

The degree of scale economies is usually measured by the proportionate change in cost resulting from a proportionate change in output along the expansion path where input prices and other variables are held fixed and costs are minimized at every level of output (Hanoch, 1975; Chambers, 1988). This measure of scale economies is not, however, appropriate for the steel firm in which pollution is produced as a byproduct. The problem is that as the output of steel production changes, other variables do not remain fixed. In particular, the level of pollution, and hence pollution abatement, increases due to an increase in steel production, which leads to an upward shift of the cost curve. Thus the total change in cost resulting from a change in steel production is the sum of a change in cost due to a change in steel output with pollution abatement held fixed and a change in cost due to pollution abatement as pollution abatement changes.

Formally, the degree of scale economies (SE) allowing for pollution abatement is measured by

$S E=\varepsilon_{C Y}+k \varepsilon_{C A}$

where $\varepsilon_{C Y}$ is the cost elasticity of output defined by

$\varepsilon_{C Y} \equiv \partial \operatorname{In} C / \partial \operatorname{In} Y, \varepsilon_{C A}$ is the cost elasticity of pollution abatement defined by $\varepsilon_{C A} \equiv \partial \operatorname{In} C / \partial \operatorname{In} A$ and $k \equiv d \operatorname{In} A / d \operatorname{In} Y$ a ratio of the percentage change in pollution abatement to the percentage change in steel production. Here, a $1 \%$ increase in steel production brings about a $k \%$ increase in pollution abatement, incurring a $k \varepsilon_{C A} \%$ increase in cost. $\mathrm{SE}<1$ implies the existence of economies of scale; $\mathrm{SE}=1$ implies constant returns to scale; and $\mathrm{SE}>1$ implies

6 It is assumed here that pollution emissions are not purchased or sold in a traditional market. Under the 1990 Clean Air Act Amendments, however, emissions trading markets will be established for power generating utilities. Thus pollution emissions can be priced directly in the regions where these markets apply, and the emissions price can be considered as the opportunity cost of compliance with pollution control. For the majority of industries at present, however, traditional command and control regulations impose a price on emissions in the form of the costs associated with the purchase and operation of pollution control equipment. 
diseconomies of scale. When $k=0$, (7) gives rise to the conventional measure of scale economies given by $\varepsilon_{C Y}$ (Chambers, 1988; Diewert and Fox, 2008) ${ }^{7}$

\section{Adjusting Total Factor Productivity Growth for Non- competitive Behavior}

The rate of growth of total factor productivity (TFP) is measured by (Diewert, 1981)

$\frac{d \operatorname{In} T F P}{d t}=\frac{d \operatorname{In} Y}{d t}-\sum_{i=1}^{n} \frac{w_{i} x_{i}}{p Y} \frac{d \operatorname{In} x_{i}}{d t}$

which represents the growth in output not accounted for by the growth in inputs, where $t$ is time. Most studies of productivity rest on the assumptions of constant returns to scale and competitive product markets with marginal cost pricing (Gollop and Jorgenson, 1980; Gollop and Roberts, 1983). For the steel industry, however, these assumptions are not likely to be appropriate. The industry is subject to imperfect competition and marginal cost pricing is valid only under non-increasing returns to scale. The steel industry is also expected to experience economies of scale or increasing returns to scale because of the relative capital intensity of the production process.

Assume that the steel industry adopts a markup pricing such that $p=A C(1+m)$, where $A C=C / Y$, the average cost of output, and $m=(p-A C) / A C$, the markup ratio. ${ }^{8}$ It can be shown that the markup ratio is related to the price elasticity of demand and the cost elasticity of output by $m=\left(\eta \varepsilon_{C Y}-1-\eta\right) /(1+\eta),{ }^{9}$ Under constant returns to scale (as defined in the conventional sense, i.e., $\varepsilon_{C Y}=1$ ), $m=-1 /(1+\eta)$, ; thus the markup ratio is inversely related to the price elasticity of demand. The value of $\mathrm{m}$ implicitly measures the degree of market power of an industry. For the competitive firm with marginal cost pricing, $m=\varepsilon_{C Y}-1$. For the competitive firm with constant returns to scale (as defined in the conventional sense), $m=0$. If the industry is not perfectly competitive, $m \neq 0$. Under the markup pricing rule, the TFP growth equation (8) can be rewritten as

$\frac{d \operatorname{In} T F P}{d t}=\frac{d \operatorname{In} Y}{d t}-\frac{1}{(1+m)} \sum_{i=1}^{n} S_{i} \frac{d \operatorname{In} x_{i}}{d t}$

where $S_{i} \equiv w_{i} x_{i} / C$ the cost share of the ith $(\mathrm{i}=1, \ldots, \mathrm{n})$ input, whose sum equals unity. Under constant returns to

7 In the special case in which $k=1$ equation (9) gives a measure of multiproduct scale economies that treats pollution abatement as an output (see Baumol, Panzar, and Willig, 1982; see also Pittman, 1981). For an empirical analysis, see Kim (1987).

8 Markup ratio can also be defined over marginal cost instead of average cost. However, markup over average cost is intuitively appealing and gives rise to TFP growth equation that is more readily interpretable.

9 From $\varepsilon_{C Y}=(\partial C / \partial Y) / A C$ we get $\partial C / \partial Y=\varepsilon_{C Y} A C$ Substituting this expression for $\partial C / \partial Y$ into (5) yields $p=A C\left(\varepsilon_{C Y} /(1+1 / \eta)\right)$ $=A C(1+m)$. Now equating $\left(\varepsilon_{C Y} /(1+1 / \eta)\right)$ to $(1+m)$ gives the desired expression for $m$ scale with marginal cost pricing, equation (9) yields the conventional TFP growth index.

Logarithmically totally differentiating $C=\sum_{i=1}^{n} w_{i} x_{i}$ with respect to time and rearranging terms yields the expression:

$\sum_{i=1}^{n} S_{i} \frac{d \operatorname{In} x_{i}}{d t}=\frac{d \operatorname{In} C}{d t}-\sum_{i=1}^{n} S_{i} \frac{d \operatorname{In} w_{i}}{d t}$

Now logarithmically totally differentiating the cost function (1) with respect to time, we find

$$
\begin{aligned}
& \frac{d \operatorname{In} C}{d t}=\varepsilon_{C Y} \frac{d \operatorname{In} Y}{d t}+\varepsilon_{C A} \frac{d \operatorname{In} A}{d t}+\sum_{i=1}^{n} S_{i} \frac{d \operatorname{In} w_{i}}{d t}+ \\
& \varepsilon_{C R} \frac{d \operatorname{In} R}{d t}+\varepsilon_{C T} \frac{d \operatorname{In} T}{d t}
\end{aligned}
$$

where $\varepsilon_{C R} \equiv$ is the cost elasticity of R\&D defined by $\varepsilon_{C R} \equiv \partial \operatorname{In} C / \partial \operatorname{In} R$, and $\varepsilon_{C T}$ is the cost elasticity of technical change defined by $\varepsilon_{C T}=\partial \operatorname{In} C / \partial \operatorname{In} T$. In addition, $S_{i}=\partial \operatorname{In} C / \partial \operatorname{In} w_{i},(\mathrm{i}=1, \ldots, \mathrm{n})$ from Shephard's lemma. Substituting (10) and (11) into (9), we obtain the TFP growth equation:

$$
\begin{aligned}
& \frac{d \operatorname{In} T F P}{d t}=\frac{\left(1+m-\varepsilon_{C Y}\right)}{(1+m)} \frac{d \operatorname{In} Y}{d t}-\frac{\varepsilon_{C A}}{(1+m)} \frac{d \operatorname{In} A}{d t} \\
& -\frac{\varepsilon_{C R}}{(1+m)} \frac{d \operatorname{In} R}{d t}-\frac{\varepsilon_{C T}}{(1+m)} \frac{d \operatorname{In} T}{d t}
\end{aligned}
$$

Equation (12) contains the sources of TFP growth. ${ }^{10}$ The first term on the right-hand side describes the scale effect of productivity growth, which is characterized by a movement along the average cost curve. Given a markup ratio, economies of scale $\left(\varepsilon_{C Y}<1\right.$ tend to magnify the effects of output growth on productivity. Further, for a given markup ratio the scale component of TFP growth would be zero regardless of the extent of output growth if competitive marginal cost pricing prevails, i.e., if $m=\varepsilon_{C Y}-1$. The second term represents the productivity effect of pollution abatement, which is characterized by a vertical displacement of the average cost curve. To the extent that pollution control imposes a resource constraint $\left(\varepsilon_{C A}>0\right)$ an increase in pollution abatement will reduce productivity growth. If, however, pollution control drives technological innovations that reduce costs $\left(\varepsilon_{C A}<0\right)$ an increase in pollution abatement will raise productivity growth. The third term measures the effect of $R \& D$ stock on

10 Equation (12) is similar to that derived from Nadiri and Schankerman (1981a) who allowed for the effect of R\&D, but not of pollution abatement, on productivity growth. However, they did not consider the relation among the markup ratio, the price elasticity of demand, and the cost elasticity of output. Moreover, they treated the $\mathrm{R} \& \mathrm{D}$ variable as a direct productive input by estimating its service price -- like the rental price of capital -- assuming that the firm optimally adjusts R\&D stock. This study, in contrast, does not assume the firm's optimal behavior with respect to $R \& D$, and $R \& D$ is included as a factor affecting productivity growth; thus there is no need to estimate the service price of R\&D as in Nadiri and Schankerman (1981a,b). Instead, the cost elasticity of $R \& D$ is needed. 
productivity. This effect also results in a shift of the average cost curve. The last term measures the productivity contribution of technical change. If there is technical progress, it leads to a downward shift of the average cost curve. The decomposition of the TFP growth in (12) requires information about the markup ratio and the cost elasticities of output, pollution abatement, $\mathrm{R} \& \mathrm{D}$, and technical change along with growth rates of these variables. Many studies of productivity, in contrast, rest on a regression framework relating productivity (typically labor productivity) to pollution abatement or R\& D (see Crandall 1981b; Mansfield 1980). The regression framework fails to identify the channel whereby variables affect productivity.

\section{THE EMPIRICAL MODEL}

The foregoing theoretical considerations give proper guidance for the specification of the empirical model. To estimate and identify the separate effects of TFP growth requires a functional specification of the cost function (1).

\section{A Translog Specification of the Cost Function}

Consider the cost function specified by a popular translog form (Christensen, Jorgenson, and Lau, 1973):

$$
\begin{aligned}
& \operatorname{In} C=\alpha_{0}+\alpha_{Y} \operatorname{In} \hat{Y}+\alpha_{A} \operatorname{In} A+\sum_{i} \beta_{i} \operatorname{In} w_{i} \\
& +\alpha_{R} \operatorname{In} R+(1 / 2) \alpha_{Y Y}(\operatorname{In} \hat{Y})^{2}+\alpha_{Y A} \operatorname{In} \hat{Y} \operatorname{In} A \\
& +\sum_{i} \delta_{Y i} \operatorname{In} \hat{Y} \operatorname{In} w_{i}+\rho_{Y R} \operatorname{In} \hat{Y} \operatorname{In} R+(1 / 2) \alpha_{A A}(\operatorname{In} A)^{2} \\
& +\sum_{i} \delta_{A i} \operatorname{In} A \operatorname{In} w_{i}+\rho_{Y R} \operatorname{In} A \operatorname{In} R+ \\
& (1 / 2) \sum_{i} \sum_{j} \beta_{i j} \operatorname{In} w_{i} \operatorname{In} w_{j}+\sum_{i} \phi_{i R} \operatorname{In} w_{i} \operatorname{In} R+\gamma_{R R}(\operatorname{In} R)^{2}
\end{aligned}
$$

where i, j $=\mathrm{K}, \mathrm{L}, \mathrm{E}, \mathrm{M}$. Symmetry implies that $\beta_{i j}=\beta_{j i}(i \neq j)$ and linear homogeneity in input prices implies the parametric restrictions:

$\sum_{i} \beta_{i}=1, \sum_{i} \delta_{Y i}=\sum_{i} \delta_{A i}=\sum_{i} \beta_{i j}=\sum_{j} \beta_{i j}=\sum_{i} \phi_{i R}=0(14)$

Technical change over the time period under consideration was, to a considerable extent, embodied in the BOF process that greatly enlarged the scale of output. To capture this aspect, we assume that technical change occurs in an "outputaugmenting" form such that $\widehat{Y} \equiv Y e^{\theta T}$ where $\theta$ is the rate of change in output due to technical change. ${ }^{11}$

Applying Shephard's lemma to (13), we obtain the cost share equations:

$S_{i}=\frac{\partial \operatorname{In} C}{\partial \operatorname{In} w_{i}}=\beta_{i}+\delta_{Y I} \operatorname{In} \hat{Y}+\delta_{A i} \operatorname{In} A+\sum_{j} \beta_{i j} \operatorname{In} w_{j}+\phi \operatorname{In} R(15)$

for $\mathrm{i}=\mathrm{K}, \mathrm{L}, \mathrm{E}, \mathrm{M}$. Logarithmically differentiating (13) with respect to $\mathrm{Y}, \mathrm{A}, \mathrm{R}$, and $\mathrm{T}$ yields the following cost elasticities:

11 Other specifications of technical change were tried, but turned out to be unsuccessful.

$$
\begin{aligned}
& \varepsilon_{C Y}=\alpha_{Y}+\alpha_{Y Y} \operatorname{In} \hat{Y}+\alpha_{Y A} \operatorname{In} A+\sum_{i} \delta_{Y i} \operatorname{In} w_{i}+\rho_{Y R} \operatorname{In} R \\
& \varepsilon_{C A}=\alpha_{A}+\alpha_{Y A} \operatorname{In} \hat{Y}+\alpha_{A A} \operatorname{In} A+\sum_{i} \delta_{A i} \operatorname{In} w_{i}+\rho_{A R} \operatorname{In} R \\
& \varepsilon_{C R}=\alpha_{R}+\alpha_{Y R} \operatorname{In} \hat{Y}+\alpha_{Y R} \operatorname{In} A+\sum_{i} \delta_{i R} \operatorname{In} w_{i}+\rho_{R R} \operatorname{In} R
\end{aligned}
$$

and

$$
\varepsilon_{C T}=\left(\alpha_{Y}+\alpha_{Y Y} \operatorname{In} \hat{Y}+\alpha_{Y A} \operatorname{In} A+\sum_{i} \delta_{Y I} \operatorname{In} w_{i}+\rho_{Y R} \operatorname{In} R\right) \theta T
$$

The cost elasticities of these variables are used to derive the degree of scale economies and TFP growth.

The profit-maximizing MR = MC condition (5) gives

$$
\frac{p Y}{C}=\left(1+\frac{1}{\eta}\right)^{-1}\left(\alpha_{Y}+\alpha_{Y Y} \ln \widehat{Y}+\alpha_{Y A} \ln A+\sum_{i} \delta_{Y i} \ln w_{i}+\rho_{Y R} \ln R\right) .
$$

To estimate the price elasticity of demand $\eta$, the demand for steel equation must be specified, which takes the form:

$$
\operatorname{In} Y=b_{0}+\eta \operatorname{In} p+b_{2} \operatorname{In} P_{\text {import }}+b_{3} \operatorname{In} V
$$

where $\mathrm{p}$ is the domestic price of steel, $P_{\text {import }}$ is the import price of steel, and $\mathrm{V}$ is an index of products made with steel, measured by the level of aggregate industrial production. ${ }^{12}$ The majority of steel imports during the time period under study came from Japan. Thus the import price of steel largely reflects the Japanese steel price adjusted by changes in the exchange rate between the U.S. and Japan. Much of steel demand originates in the construction and automotive industries, whose activities are highly affected by aggregate industrial production in the economy.

\section{Tests of Hypotheses}

As shown in the previous section, the measure of scale economies allowing for pollution abatement is defined as the sum of the cost elasticities of steel output and pollution abatement adjusted by $k$ from (16) and (17), we get

$$
\begin{aligned}
& S E=\left(\alpha_{Y}+k \alpha_{A}\right)+\left(\alpha_{Y Y}+k \alpha_{Y A}\right) \operatorname{In} Y+\left(\alpha_{Y A}+k \alpha_{A A}\right) \operatorname{In} A \\
& \sum_{i}\left(\delta_{Y i}+k \delta_{A i}\right) \operatorname{In} w_{i}+\left(\rho_{Y R}+k \rho_{A R}\right) \operatorname{In} R
\end{aligned}
$$

The most important scale hypothesis is whether or not the production technology exhibits constant returns to scale. From (22), this requires that the following parameter restrictions on (13) hold:

$$
\begin{aligned}
& \alpha_{Y}+k \alpha_{A}=1 \\
& \alpha_{Y Y}=\alpha_{Y A}=\alpha_{A A}=\delta_{Y K}=\delta_{Y L}=\delta_{Y E}=\delta_{Y M}=\delta_{A K} \\
& =\delta_{A L}=\delta_{A E}=\delta_{A M}=\rho_{Y R}=0
\end{aligned}
$$

In the analysis of the productivity effect of pollution control, it is commonly maintained that pollution abatement costs are separable from the costs of producing output by treating pollution abatement costs as additive increments to the direct production costs (Denison, 1979; Kopp and Smith, 1981).

12 Various specifications of the demand function were tried by including other variables. But they turned out to be insignificant, so they were excluded in the final analysis. 
This implicitly assumes that pollution abatement expenditures divert equivalent expenditures on factor inputs. As such, an increase in pollution abatement expenditures systematically reduces productivity in known proportion to the ratio of this expenditure increase to total production cost. The cost function (1) can then be rewritten as the sum of production and pollution abatement costs:

$$
C(Y, A, \mathbf{W}, R, T)=C(Y, \mathbf{W}, R, T)+C(A, \mathbf{W}, R, T)
$$

which implies that marginal cost of steel production is independent of changes in pollution abatement, i.e., $\partial^{2} C / \partial A \partial Y=0,{ }^{13}$ A necessary condition for (24) to hold is that $\alpha_{Y A}+\alpha_{Y} \alpha_{A}=0$.

Furthermore, in the TFP growth equation (12), changes in pollution abatement are hypothesized to have an important effect on productivity growth. However, if pollution abatement has no productivity effect, $\varepsilon_{C A}=0$ for a given markup ratio. In this case all parameters related to pollution abatement in the cost function would be zero. From (17), this implies the following parameter restrictions on (13):

$\alpha_{A}=\alpha_{Y A}=\alpha_{A A}=\delta_{A K}=\delta_{A L}=\delta_{A E}=\delta_{A M}=\rho_{A R}=0$

$\mathrm{R} \& \mathrm{D}$ is also presumed to be an important factor affecting productivity growth. If $\mathrm{R} \& \mathrm{D}$ has no productivity effect, $\varepsilon_{C R}=0$ for a given markup ratio. Then from (18) we have

$\gamma_{R}=\rho_{Y R}=\rho_{A R}=\phi_{K R}=\phi_{L R}=\phi_{E R}=\phi_{M R}=\lambda_{R R}=0$

The basic technical change hypothesis is that $\varepsilon_{C T}=0$. If technical change has no productivity effect, then from (19), this implies that $\theta=0$.

\section{The Estimation Method}

The translog cost function (13), the cost share equations (15), the MR = MC condition (20), and the demand for steel equation (21) form a system of simultaneous equations to be estimated. Additive disturbances are postulated for each of the equations. The disturbances are assumed to have a multivariate normal distribution with zero mean vector and constant covariance matrix, but contemporaneous correlation across equations is allowed. Since the cost shares sum to unity, the cost share equation for materials is deleted, and the maximum likelihood method is utilized to estimate the parameters, subject to symmetry $\left(\beta_{i j}=\beta_{j i}\right.$ for $\left.i \neq j\right)$ and linear homogeneity in input prices (14), which give rise to within and across restrictions on the parameters. The maximum likelihood estimates are invariant to the choice of the equation deleted.

\section{ESTIMATION AND DISCUSSION OF RESULTS}

We now proceed to discuss the results of estimating the empirical model developed in the previous section for the U.S. steel industry for the period 1956-76. A discussion of the sources of data and the construction of variables used in this study is provided in the Appendix. The majority of data used in this study are also employed by Crandall (1981a).

Table 1 presents parameter estimates for the translog cost function (13) and the demand function (21) together with asymptotic standard errors. ${ }^{14}$ The individual parameters of the translog cost function are used to estimate the cost elasticities of variables and their estimates are, by and large, significant with few exceptions. The parameter estimates of the demand function are also significant. The standard errors of the regression are low and R2's are high, indicating a good fit. The Durbin-Watson (DW) statistics leave some questions about autocorrelation. However, except for the labor share equation, their values are in the indeterminate range at the $5 \%$ level of significance, so autocorrelation appears not a serious problem for the whole system.

For the demand function, the estimated price elasticity of steel is -0.7148 , implying that the demand for steel is inelastic. The import price elasticity of 0.4577 shows that an increase in the import price of steel would lead to higher demand for domestic steel. This implies that domestic and imported steel are substitutes. A change in industrial production has a pronounced effect on the demand for steel, as evidenced by its elasticity of 0.7993 .

\section{Tests of Restricted Models}

The choice of an appropriate model is crucial in empirical analysis. To this effect, five hypotheses discussed in Section III are considered in Table 2 . These hypotheses impose restrictions on the general translog cost function (13). Likelihood ratio tests are used to compare the estimating equations with and without the corresponding restrictions imposed. The test statistic is chi-square distributed with degrees of freedom equal to the number of restrictions imposed. For constant returns to scale, two measures of scale economies are considered: the conventional measure that does not allow for the pollution abatement effect and the adjusted measure that allows for it. As can be seen from Table 2, two hypotheses of constant returns to scale are overwhelmingly rejected. ${ }^{15}$ The hypothesis of separability of production and pollution abatement costs is rejected, and the hypothesis of no pollution control effect is also rejected. In addition, hypotheses of no R\&D and technical change effects are rejected. These results suggest that the general cost function (13), which places no restrictions on technology, is a proper

14 Some problems were encountered in the joint estimation of the cost system and the demand function, which involve the convergence problem and unreasonable parameter estimates. Thus the demand equation is estimated separately.

15 For ease of estimation, $k$ was constrained to 1.
13 If pollution abatement is treated as an additional output, this condition referred to as nonjointness in production (see Baumol, Panzar, and Willig, 1982). Nonjointness means that inputs can be additively split up between separate production processes for each output.

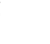


description of the underlying structure of steel production and that changes in pollution abatement, R\&D stock, and technical change have measurable effects on productivity growth in the U.S. steel industry.

Table 1. Parameter Estimates of the Cost and Demand Functions (Asymptotic Standard Errors in Parentheses).

\begin{tabular}{|c|c|c|c|}
\hline Parameter & Estimate & Parameter & Estimate \\
\hline \multicolumn{4}{|c|}{ The Cost Function } \\
\hline$\alpha_{0}$ & $\begin{array}{c}9.5814 \\
(0.0156)\end{array}$ & $\delta_{A E}$ & $\begin{array}{c}0.0045 \\
(0.0018)\end{array}$ \\
\hline$\alpha_{Y}$ & $\begin{array}{c}0.4739 \\
(0.0875)\end{array}$ & $\delta_{A M}$ & $\begin{array}{c}0.0115 \\
(0.0030)\end{array}$ \\
\hline$\alpha_{A}$ & $\begin{array}{l}-0.0251 \\
(0.0168)\end{array}$ & $\rho_{A R}$ & $\begin{array}{l}-0.2722 \\
(0.0615)\end{array}$ \\
\hline$\beta_{K}$ & $\begin{array}{c}0.3126 \\
(0.0031)\end{array}$ & $\beta_{K K}$ & $\begin{array}{c}0.2085 \\
(0.0148)\end{array}$ \\
\hline$\beta_{L}$ & $\begin{array}{c}0.4003 \\
(0.0039)\end{array}$ & $\beta_{K L}$ & $\begin{array}{l}-0.0730 \\
(0.0127)\end{array}$ \\
\hline$\beta_{E}$ & $\begin{array}{c}0.0582 \\
(0.0015)\end{array}$ & $\beta_{K E}$ & $\begin{array}{l}-0.0341 \\
(0.0064)\end{array}$ \\
\hline$\beta_{M}$ & $\begin{array}{c}0.2287 \\
(0.0033)\end{array}$ & $\beta_{K M}$ & $\begin{array}{l}-0.1013 \\
(0.0077)\end{array}$ \\
\hline$\gamma_{R}$ & $\begin{array}{c}0.0482 \\
(0.0781)\end{array}$ & $\beta_{L L}$ & $\begin{array}{c}0.2291 \\
(0.0173)\end{array}$ \\
\hline$\alpha_{Y Y}$ & $\begin{array}{c}0.4695 \\
(0.4315)\end{array}$ & $\beta_{L E}$ & $\begin{array}{l}-0.0159 \\
(0.0116)\end{array}$ \\
\hline$\alpha_{Y A}$ & $\begin{array}{l}-0.0830 \\
(0.0462)\end{array}$ & $\beta_{L M}$ & $\begin{array}{l}-0.1401 \\
(0.0096)\end{array}$ \\
\hline$\delta_{Y K}$ & $\begin{array}{l}-0.1116 \\
(0.0219)\end{array}$ & $\beta_{E E}$ & $\begin{array}{c}0.0185 \\
(0.0113)\end{array}$ \\
\hline$\delta_{Y L}$ & $\begin{array}{l}-0.0450 \\
(0.0293)\end{array}$ & $\beta_{E M}$ & $\begin{array}{c}0.0315 \\
(0.0060)\end{array}$ \\
\hline$\delta_{Y E}$ & $\begin{array}{c}0.0268 \\
(0.0107)\end{array}$ & $\beta_{M M}$ & $\begin{array}{c}0.2098 \\
(0.0093)\end{array}$ \\
\hline$\delta_{Y M}$ & $\begin{array}{c}0.1298 \\
(0.0172)\end{array}$ & $\phi_{K R}$ & $\begin{array}{c}0.0677 \\
(0.0057)\end{array}$ \\
\hline$\rho_{Y R}$ & $\begin{array}{c}0.4460 \\
(0.0642)\end{array}$ & $\phi_{L R}$ & $\begin{array}{l}-0.0422 \\
(0.0074)\end{array}$ \\
\hline$\alpha_{A A}$ & $\begin{array}{l}-0.0387 \\
(0.0228)\end{array}$ & $\phi_{E R}$ & $\begin{array}{c}0.0003 \\
(0.0027)\end{array}$ \\
\hline$\delta_{A K}$ & $\begin{array}{l}-0.0073 \\
(0.0035)\end{array}$ & $\phi_{M R}$ & $\begin{array}{l}-0.0258 \\
(0.0039)\end{array}$ \\
\hline$\delta_{A L}$ & $\begin{array}{c}-0.0086 \\
(0.00519)\end{array}$ & $\gamma_{R R}$ & $\begin{array}{c}0.2328 \\
(0.0253)\end{array}$ \\
\hline & & $\theta$ & $\begin{array}{l}-0.2325 \\
(0.0557)\end{array}$ \\
\hline
\end{tabular}




\begin{tabular}{|c|c|c|c|}
\hline \multicolumn{4}{|c|}{ The Demand Function } \\
\hline$b_{0}$ & $\begin{array}{c}0.0980 \\
(0.0284)\end{array}$ & $\eta$ & $\begin{array}{l}-0.7148 \\
(0.3974)\end{array}$ \\
\hline$b_{2}$ & $\begin{array}{c}0.4577 \\
(0.2247)\end{array}$ & $b_{3}$ & $\begin{array}{c}0.7993 \\
(0.1351)\end{array}$ \\
\hline \multicolumn{4}{|c|}{ Summary Statistics } \\
\hline Equation & Standard Error of Regression & $\mathbf{R}^{2}$ & DW \\
\hline Cost & 0.0135 & 0.95 & 2.2224 \\
\hline Capital share & 0.0067 & 0.96 & 1.6853 \\
\hline Labor share & 0.0122 & 0.81 & 2.3817 \\
\hline Energy share & 0.0032 & 0.89 & 1.9369 \\
\hline MR - MC & 0.0198 & 0.91 & 1.2443 \\
\hline Demand & 0.0743 & 0.87 & 1.4137 \\
\hline \multicolumn{3}{|c|}{ Log of likelihood function } & 321.637 \\
\hline
\end{tabular}

Table 2. Test Statistics for Restricted Models.

\begin{tabular}{|c|c|c|c|}
\hline \multirow{2}{*}{ Hypothesis } & \multirow{2}{*}{ Test Statistic ${ }^{a}$} & \multicolumn{2}{|c|}{$\underline{\text { Critical Value }}$} \\
\hline & & $1 \%$ & $5 \%$ \\
\hline \multicolumn{4}{|l|}{ Constant returns to scale } \\
\hline w/o adjustment for pollution abatement & 96.229 & 18.475 & 14.067 \\
\hline w/ adjustment for pollution abatement & 113.306 & 26.217 & 21.026 \\
\hline Additivity of production and pollution abatement costs & 12.533 & 6.635 & 3.841 \\
\hline No pollution abatement effect & 38.000 & 18.475 & 14.067 \\
\hline No $R \& D$ effect & 43.178 & 18.475 & 14.067 \\
\hline No technical change effect & 9.467 & 6.635 & 3.841 \\
\hline
\end{tabular}

a Minus twice the difference between the log likelihood values for the restricted and restricted models.

\section{The Growth of Relevant Variables}

Since productivity growth involves time changes, it is instructive to see how variables affecting TFP growth have changed over time. Table 3 reports average annual growth rates of steel output, pollution abatement, $R \& D$ stock, and technical change. The average annual growth rate of output was $0.37 \%$ over the $1957-76$ period, implying that there was virtually no increase in steel production in this period. However, output growth rates varied considerably for distinct subperiods. When the sample is broken into two subperiods, output grew at the annual average rate of $1.31 \%$ during $1957-66$, but grew at a negative rate of $0.57 \%$ during $1967-$ 76. When the sample is divided into four subperiods, the highest output growth took place in 1962-66, but steel production underwent negative growth in 1957-61 and 1967-71.
The average annual output growth rate in the 1970's was about $1 \%$. (A detailed discussion of factors affecting output growth follows later.)

Pollution abatement grew at an annual rate of $10.10 \%$ during the sample period. During 1957-66, it grew at an average rate of $4.14 \%$ per year and jumped to a very high rate of $16.05 \%$ per year during 1967-76. Looking at four subperiods, pollution abatement grew at a negative rate of $4.68 \%$ per year in 1957-61, while the greatest increase of $16.81 \%$ per year occurred in 1967-71. It must be remembered that the regulation of environmental or pollution conditions in the United States began in earnest with the creation of the Environmental Protection Agency (EPA) by passing the Clean Air Act Amendments in 1970 and the Clean Water Act Amendments in 1972. 
Table 3. Average Annual Growth Rates of Variables (Average Annual Percentages).

\begin{tabular}{|c|c|c|c|c|}
\hline Period & Output & Pollution Abatement & R\&D & 30.10 \\
\hline $1957-61$ & -3.25 & -4.68 & 10.94 & 34.42 \\
\hline $1962-66$ & 5.86 & 12.96 & 3.82 & 14.82 \\
\hline $1967-71$ & -2.15 & 16.81 & 0.74 & 3.24 \\
\hline $1972-76$ & 1.01 & 15.28 & 20.52 & 40.54 \\
\hline $1957-66$ & 1.31 & 4.14 & 1.27 & 10.90 \\
\hline $1967-76$ & -0.57 & 16.05 & 10.10 & 24.79 \\
\hline $1957-76$ & 0.37 & & \\
\hline
\end{tabular}

R\&D stock grew at an average annual rate of $10.90 \%$ during 1956-76. The average rate of growth of R\&D stock was $20.52 \%$ per year in $1957-66$ and $1.27 \%$ per year in 1967-76. R\&D stock increased at a decreasing rate during the sample period. It is important to note from Table 3 an inverse relationship between growth rates of pollution abatement and R\&D stock. This provides clear evidence that a large fraction of R\&D funds was diverted to find ways of complying with pollution control and other regulatory constraints in the steel industry. The annual rate of growth of technical change, measured by the BOF adoption rate, was $24.79 \%$ on average but was decreasing during the sample period. In particular, the BOF adoption rate grew at an average annual rate of $40.54 \%$ in $1957-66$ but fell significantly to a rate of $9.03 \%$ in 1967-76. This suggests that although the BOF process was introduced rapidly in steel making in the mid 1950's, its adoption rate has slowed significantly over the period. Clearly, a marked decline in the rate of growth of R\&D stock and technology adoption rate was taking place during the sample period.

\section{The Cost Elasticities of Variables, Scale Economies, and Markup Ratio}

The cost elasticities of variables and the markup ratio are essential in analyzing TFP growth. The cost elasticity of a variable describes a proportionate change in cost commensurate with a $1 \%$ change in that variable. Table $\mathbf{4}$ gives the estimates of the cost elasticities of relevant variables along with the estimates of scale economies and markup ratio over the sample period. The estimated cost elasticities of output are all positive and less than one with the exception of the first three years, implying cost advantages in steel production. In fact, this is further evidenced by the estimated values of scale economies, suggesting that the underlying steel technology exhibits sizeable economies of scale. ${ }^{16}$ According to Table 4 , the average markup ratio was $25.97 \%$ per year over the sample period, and a downturn in the markup ratio in 1974-76 appears to have reflected the 1973 oil crisis. Since the markup ratio is markedly different from zero for all years, this implies that the steel industry is clearly imperfect-

16 Karlson (1983) found the same result using cross-sectional data for U.S. steel firms. He was not, however, interested in productivity analysis. ly competitive. If competitive marginal cost pricing prevails, the markup ratio is related to the cost elasticity of output by $m=\varepsilon_{C Y}-1$ which reduces to $m=0$ if $\varepsilon_{C Y}=1$. Since $\varepsilon_{C Y}<1$ for the entire sample period, this provides evidence against marginal cost pricing, implying non-competitive behavior of the steel industry.

The estimated cost elasticity of pollution abatement is positive from 1956 through 1966 and negative from 1967 through 1976. This means that the steel industry incurred a positive marginal abatement cost of pollution in the early period, but pollution control led to declining costs in the latter period. It appears that there was a considerable resource diversion in steel production entailed by pollution control in the early period. However, in the latter period compliance with more stringent pollution standards (or more vigorous enforcement of the pollution laws) appears to have provided an added incentive for the industry to adopt the BOF technology, thereby reducing costs. ${ }^{17}$ In particular, the BOF adoption rate was $17.5 \%$ in 1965 ; it increased to $48.2 \%$ in 1970 and to $61.6 \%$ in 1975 when pollution control standards became increasingly stringent. It is known that a (new) BOF unit is cheaper to build than an (old) open hearth unit and better lends itself to automation and pollution control (Lynn, 1981). ${ }^{18}$ Interestingly, similar evidence was uncovered by Bresnahan and Yao (1985) for the automobile industry. According to them, the increasing stringency of automobile emission regulations forced car manufacturers to expand their technological base. This regulation-induced technical change caused the cost of compliance in car manufacturing to decrease despite new stricter emissions standards.

17 It is also found that pollution abatement decreases marginal cost of steel production. The effect of pollution abatement on marginal cost of production (evaluated at the point of approximation of the translog cost function) is given by $\alpha_{Y A}+\alpha_{Y} \alpha_{A}$. From Table 1, the estimate is negative, suggesting that an increase in pollution abatement decreases marginal cost of production.

18 In this regard, one steel executive states that the deciding factor which induced his company to build a new basic oxygen unit and close an open hearth unit was that pollution control equipment for the open hearth would cost \$12 million compared to \$4 million for similar equipment for the basic oxygen furnaces, even though their steel making capacities were comparable (Federal Trade Commission Report, 1977, p. 144) 
Stricter pollution control requirements are likely to bring about a reduction in costs through a change in the optimal input mix. In particular, an increase in pollution control requirements tends to have a capital and labor - saving effect on input use of steel production. Since capital and labor constitute a significant portion of steel production cost, a substantial cost savings can be expected to occur in compliance with a tighter pollution control regulation. ${ }^{19}$ This reflects the fact that, to the extent that pollution abatement regulations render a large part of the capital stock obsolete because preexisting capital equipment cannot be easily adapted to pollution control technology, it may be less costly to retire the capital early than to operate it. It must be pointed out, however, that tighter pollution control regulations increase compliance costs, whereas increased efficiency from modernization and in the use of inputs decreases the costs of pollution abatement. When these two effects are taken into account, we find that the increased efficiency from pollution control more than offset the resource diversion due to compliance in the latter period.

Turning to the $R \& D$ elasticities, the estimates are negative for some years but are, by and large, positive, which appears rather puzzling. An investment in R\&D in general leads to innovations that results in more efficient production, causing a downward shift of the average cost curve; the cost elasticity of $R \& D$ would then be negative. $R \& D$ investment directed toward the development of new or improved processes or products can be expected to have this effect. A positive value of $R \& D$ elasticity, however, indicates that $R \& D$ activity in the steel industry has not been productive in terms of reducing costs. ${ }^{20}$ This appears to suggest that the steel industry used $R \& D$ funds mostly for consumption rather than for investment. ${ }^{21}$ Technical change brings about the decreased use of inputs, leading to declining costs. With the exception of the first three years, the technical change elasticities are all negative, and the estimates have increased steadily (in absolute size) over time up to 1973 . This reflects a substantial cost-reducing effect of the BOF diffusion process in steel production. The positive value of the cost elasticity of technical change in the 1956-58 period, however, implies technical regression.

19 The cost elasticity of a variable can be shown to be the weighted sum of input demand elasticities, with the weight given by the cost shares. The estimated input demand elasticity with respect to pollution abatement evaluated at the sample midpoint (1967) is -0.0419 for capital, -0.0400 for labor, 0.0615 for energy, and 0.0377 for materials, respectively. This means that an increase in pollution control reduces the demand for capital and labor and increases the demand for energy and materials. The resulting cost elasticity of pollution abatement is -0.0186 .

20 Many studies of $R \& D$ examine the effect of $R \& D$ on output (see Griliches, 1988). The elasticity of output with respect to R\&D ( $\left.\varepsilon_{Y R}\right)$ can be derived from the cost function by $\varepsilon_{Y R}=-\varepsilon_{C R} / \varepsilon_{C Y}$. Using the estimates for $\varepsilon_{C R}$ and $\varepsilon_{C Y}$ from Table 4, the average elasticity of R\&D over the sample period is -0.0417 , which suggests a negative effect on output.

21 To the extent that R\&D activity aimed only at process (not product) improvement raises productivity (Scherer, 1982), this result also suggests that R\&D activity in the steel industry was geared to product improvement. Further, it can be argued that the steel industry experienced diminishing returns from $\mathrm{R} \& \mathrm{D}$ due to the exhaustion of inventive opportunities (Griliches, 1988).

\section{Productivity Growth and Its Determinants}

The growth rate of TFP is computed for each year of the sample period by using the required growth rates of variables taken from Table $\mathbf{3}$ and the cost elasticities and the markup ratio from Table 4 . Table 5 identifies the mean annual contribution of each source of TFP growth to the average annual rate of growth of TFP in each subperiod. The entries in the table are calculated using Törnqvist discrete approximations to continuous variables for $\mathrm{Y}, \mathrm{A}, \mathrm{R}$, and $\mathrm{T}$ in the TFP growth rate in (12). The average annual rate of TFP growth during $1957-76$ was $1.07 \%$. From 1957 to 1966 , TFP grew at an average rate of $1.24 \%$ per year, and it grew at an average rate of $0.91 \%$ per year from 1967 to 1976 . However, there was considerable variation in TFP growth across four subperiods. From 1957 to 1961, TFP grew at a negative annual rate of $1.56 \%$. From 1962 to 1966 , a drastic reversal took place; TFP experienced a relatively high growth rate of $4.05 \%$ per year in this period. From 1967 to 1972, TFP growth fell sharply to $0.14 \%$ per year, and it rose to $1.68 \%$ per year from 1972 to 1976 . The average annual rate of $1.07 \%$ in TFP growth in the steel industry in the 1957-76 period is of small magnitude but appears modest relative to those of other industries (Gollop and Jorgenson, 1980; Griliches, 1988). Further, the estimated TFP growth rates are compared with the BLS's labor productivity (LP) growth rate, which shows that labor productivity growth is, in general, higher than TFP growth.

The decomposition of TFP growth isolates the underlying components of productivity growth associated with scale, pollution abatement, R\&D stock, and technical change effects. For the entire period, the scale effect on average reduced annual TFP growth by 0.01 percentage points. This appears relatively small in magnitude, accounting for a $0.93 \%$ reduction in the $1.07 \%$ rate of increase in TFP. However, it grossly masks the important variation of the scale contribution across subperiods. In fact, the scale effect was the dominating force in TFP growth in the steel industry. For example, in 1957-61 the scale effect reduced TFP growth by 3.38 percentage points per year, accounting for the largest negative contribution to TFP growth in this period. In contrast, in 1962-66 the scale effect increased TFP growth by 4.02 percentage points per year, which accounts for the greatest positive contribution to TFP growth in this period. In 1967-71, the scale effect made a negative contribution of 1.37 percentage point to TFP growth, still accounting for the largest negative contribution in this period. However, in 1972-76 the scale effect rebounded to make a 0.68 percentage point contribution to TFP growth.

In order to understand the variation in the scale effect across subperiods, it is important to note that the degree of scale economies (more precisely the cost elasticity of output) and output growth rates mainly determine the scale contribution to TFP growth. Since the steel industry has experienced pervasive economies of scale in the sample period, output growth rates will have a major influence on the scale effect in TFP growth. Indeed, the pattern of the scale effect over the subperiods reflects considerable variability of changes in output (see Table 3), which largely explains the retardation of TFP in the steel industry. This indicates that scale economies in production have not played a large role as a contrib- 
uting factor to TFP growth over the sample period. It appears that when steel demand exhibited increasing variability, the steel industry was adjusting by altering capacity utilization rates in preference to adding fixed capital stocks. With sluggish output growth, the steel industry was operating with considerable excess capacity during the sample period with capacity utilization averaging around $81.32 \%$ (Crandall, 1981a). This excess capacity restrained plant expansion plans and retarded productivity growth in the steel industry

Table 4. Estimated Cost Elasticities of Relevant Variables, Scale Economies, and Markup Ratio.

\begin{tabular}{|c|c|c|c|c|c|c|}
\hline \multirow[b]{2}{*}{ Year } & \multicolumn{4}{|c|}{ Elasticity of Cost with Respect to } & \multirow[b]{2}{*}{ Scale Economies } & \multirow[b]{2}{*}{ Markup Ratio (\%) } \\
\hline & Output & Pollution Abatement & $\mathbf{R} \& \mathbf{D}$ & Technical Change & & \\
\hline 1956 & -0.4379 & 0.5872 & -0.1819 & 0.0004 & 0.1492 & 28.52 \\
\hline 1957 & -0.1379 & 0.4292 & -0.0128 & 0.0002 & 0.2912 & 25.18 \\
\hline 1958 & -0.1317 & 0.3836 & -0.0704 & 0.0005 & 0.2518 & 31.56 \\
\hline 1959 & 0.0508 & 0.2969 & 0.0492 & -0.0002 & 0.3477 & 29.31 \\
\hline 1960 & 0.1459 & 0.2432 & 0.0876 & -0.0011 & 0.3892 & 26.96 \\
\hline 1961 & 0.2236 & 0.2027 & 0.1073 & -0.0021 & 0.4264 & 23.18 \\
\hline 1962 & 0.2843 & 0.1597 & 0.1336 & -0.0037 & 0.4440 & 32.45 \\
\hline 1963 & 0.3504 & 0.1185 & 0.2082 & -0.0063 & 0.4690 & 22.38 \\
\hline 1964 & 0.4452 & 0.0755 & 0.2611 & 0.0125 & 0.5208 & 20.06 \\
\hline 1965 & 0.4873 & 0.0457 & 0.2764 & -0.0197 & 0.5330 & 24.62 \\
\hline 1966 & 0.4862 & 0.0049 & 0.1820 & -0.0286 & 0.4911 & 24.17 \\
\hline 1967 & 0.4407 & -0.0186 & 0.0130 & -0.0333 & 0.4220 & 21.71 \\
\hline 1968 & 0.4667 & -0.0365 & 0.0161 & -0.0402 & 0.4301 & 31.25 \\
\hline 1969 & 0.4995 & -0.0617 & 0.0147 & -0.0495 & 0.4377 & 21.69 \\
\hline 1970 & 0.4898 & -0.0698 & -0.1111 & -0.0548 & 0.4200 & 22.50 \\
\hline 1971 & 0.4468 & -0.0561 & -0.1144 & -0.0551 & 0.3906 & 30.77 \\
\hline 1972 & 0.4724 & -0.0641 & -0.1280 & -0.0614 & 0.4082 & 26.34 \\
\hline 1973 & 0.5904 & -0.0504 & 0.1580 & -0.0758 & 0.5405 & 30.49 \\
\hline 1974 & 0.5504 & -0.0790 & 0.0147 & -0.0716 & 0.4713 & 24.52 \\
\hline 1975 & 0.4339 & -0.0813 & -0.3345 & -0.0621 & 0.3526 & 25.86 \\
\hline 1976 & 0.4359 & -0.0735 & -0.3340 & -0.0632 & 0.3623 & 21.95 \\
\hline Average & 0.3139 & 0.0931 & 0.0131 & -0.0305 & 0.4071 & 25.97 \\
\hline
\end{tabular}

Table 5. Decomposition Of TFP Growth (Average Annual Percentage Rates of Changea)

\begin{tabular}{|c|c|c|c|c|c|c|}
\hline \multirow[b]{2}{*}{ Period } & \multirow[b]{2}{*}{ LP Growth Rate ${ }^{b}$} & \multirow[b]{2}{*}{ TFP Growth Rate ${ }^{\mathrm{c}}$} & \multicolumn{4}{|c|}{ Sources of TFP Growth } \\
\hline & & & Scale Effect & Pollution Effect & R\&D Effect & Technical Change Effect \\
\hline
\end{tabular}




\begin{tabular}{|c|c|c|c|c|c|c|}
\hline $1962-66$ & 3.90 & $\begin{array}{l}4.05 \\
(100)\end{array}$ & $\begin{array}{c}4.02 \\
(99.26)\end{array}$ & $\begin{array}{c}-0.54 \\
(-12.35)\end{array}$ & $\begin{array}{c}-1.71 \\
(-42.22)\end{array}$ & $\begin{array}{c}2.28 \\
(56.30)\end{array}$ \\
\hline $1972-76$ & 1.49 & $\begin{array}{l}1.68 \\
(100)\end{array}$ & $\begin{array}{c}0.68 \\
(40.48)\end{array}$ & $\begin{array}{c}1.07 \\
(63.69)\end{array}$ & $\begin{array}{c}0.36 \\
(-21.43)\end{array}$ & $\begin{array}{c}0.29 \\
(17.26)\end{array}$ \\
\hline 1957-66 & 1.76 & $\begin{array}{l}1.24 \\
(100)\end{array}$ & $\begin{array}{c}0.32 \\
(25.81)\end{array}$ & $\begin{array}{c}0.46 \\
(37.10)\end{array}$ & $\begin{array}{c}-0.55 \\
(-44.35)\end{array}$ & $\begin{array}{c}1.01 \\
(81.44)\end{array}$ \\
\hline 1967-76 & 1.04 & $\begin{array}{l}0.91 \\
(100)\end{array}$ & $\begin{array}{c}-0.34 \\
(-37.36)\end{array}$ & $\begin{array}{c}0.72 \\
(79.12)\end{array}$ & $\begin{array}{c}-0.21 \\
(-23.08)\end{array}$ & $\begin{array}{c}0.74 \\
(81.32)\end{array}$ \\
\hline
\end{tabular}

a The numbers in parentheses refer to percentage contributions of the components of TFP growth.

b Average annual labor productivity growth rate in the steel industry. The authors' calculations taken from the Handbook of Labor Statistics.

c The sum of scale, pollution abatement, R\&D, and technical change effects.

Pollution abatement, in general, had a positive effect on TFP growth in 1957-76. On average, the pollution abatement effect increased TFP growth by 0.58 percentage points, corresponding to $54.21 \%$ of TFP growth in 1957-76. Except for the 1962-66 period, the pollution effect is positive and its effect is strong enough to measurably affect productivity growth. In particular, the pollution abatement effect increased TFP growth by 1.07 percentage points in 1972-76, accounting for $63.69 \%$ of TFP growth. The positive cost elasticity of pollution abatement (see Table 4) accounts for this positive contribution of the pollution abatement effect to TFP growth. No empirical study has uncovered the possibility that pollution control can provide a positive inducement to productivity growth. Instead, previous studies attribute most of the productivity slowdown to pollution control or government regulations (see Crandall, 1981b; Denison, 1979; Gollop and Roberts, 1983; Smith and Sims, 1985; Conrad and Morrison, 1989; Färe et al., 1989). It must be noted that to the extent that pollution control diverts resources from steel production, it reduces productivity growth. On the other hand, when more stringent pollution laws create an added incentive for technical change that would not exist in the absence of pollution control, it will contribute to an increase in productivity growth. The ultimate impact of pollution control on productivity growth depends on which effect dominates. This study's finding suggests that the regulation-induced incentive effect can outweigh the resource diversion effect of pollution control, thus raising productivity growth.

The contribution of R\&D to productivity growth was, by and large, negative with the exception of the 1957-61 period. For example, the R\&D effect, on average, reduced TFP growth by 0.37 percentage points in 1957-76. R\&D investment that reduces the unit cost of production raises productivity. However, the estimated cost elasticity of $R \& D$ was, in general, positive (see Table 4), and the rate of growth of R\&D stock was declining over the sample period as funds were reallocated from R\&D to pollution abatement (see Table 3). This explains the pronounced negative relationship between the R\&D effect and productivity growth. Interestingly, Link (1982) presents similar evidence for a sample of U.S. manufacturing industries. He disaggregated R\&D expenditure into the activities to comply with regulations and the traditional innovative activities, and observed that a significant portion of $R \& D$ was directed in the 1970 's toward compliance with environmental regulations. The regulation-related $R \& D$ expenditures were found to be negatively related to productivity growth. Link's analysis, however, rests on a regression framework and does not consider the relationship among pollution control, R\&D, and technical change. This study's finding is in sharp contrast to most previous studies, which aver a strong positive relationship between R\&D and output or productivity growth (see Nadiri and Schankerman, 1981a; Mansfield, 1981). It is, however, indicated that R\&D had no substantial effect on the post-1973 productivity slowdown in the United States (see Griliches, 1988).

After the scale effect, technical change was the second major source of productivity growth in the steel industry. Technical change leads to greater efficiency gains, which enhance productivity growth. In the steel industry, this occurred mainly due to the diffusion of the BOF technology introduced in the mid 1950's. Technical change contributed an average of 0.87 percentage points annually in 1957-76, which accounts for $81.31 \%$ of TFP growth in this period. However, the contribution of the new technology has diminished steadily over time. The technical change effect peaked in 1962-66 and became less important afterwards. The technical change effect of 2.28\% in TFP growth during 1962-66 can be attributed to the installation of a large number of BOF plants. However, slowness to adopt BOF and other new technologies (see Table $\mathbf{3}$ ) and technical retardation is evi- 
Table 6. Average Annual Growth Rates of Demand Variables (Annual Percentages).

\begin{tabular}{|c|c|c|c|c|}
\hline Period & Output & Domestic Price of Steel & Import Price of Steel & Industrial Production \\
\hline $1957-61$ & -3.25 & 2.72 & -3.67 & 1.75 \\
\hline $1962-66$ & 5.86 & 0.60 & -1.51 & 7.67 \\
\hline $1967-71$ & -2.15 & 4.36 & -0.12 & 3.74 \\
\hline $1972-76$ & 1.01 & 10.67 & -2.59 & 3.90 \\
\hline $1957-66$ & 1.31 & 1.66 & 3.45 & 2.82 \\
\hline $1967-76$ & -0.57 & 7.51 & 0.43 & 3.77 \\
\hline
\end{tabular}

dent in the declining importance of the technical change effect over the period. ${ }^{22}$

\section{Demand Variables and Productivity Growth}

It was found that output growth was the major force driving TFP in the steel industry. It may be informative to examine factors affecting output growth and their contribution to productivity growth.

Output growth is determined by demand conditions, which were identified as the domestic and import prices of steel and aggregate industrial production. During the entire sample period, output grew at an average annual rate of $0.37 \%$, virtually a zero growth. This sluggish output growth can be, to a large extent, explained by the demand factors listed in Table 6. The domestic price of steel was increasing at an average rate of $4.58 \%$ per year, which had a substantial dampening effect on output growth during the sample period. Given the estimated price elasticity of domestic steel of -0.7148 (see Table 1), a $4.5 \%$ annual increase in the domestic steel price would have resulted in a $3.28 \%$ reduction in steel demand in this period. The import price of steel increased at an annual rate of $0.43 \%$ from 1957 to 1976 . This price increase is rather small. However, since domestic and imported steel are substitutes, only a modest increase in domestic steel demand should occur from the slow increase in the import price of steel in the sample period. U.S. industrial production grew at an average annual rate of $3.77 \%$ from 1957 to 1976. This relatively large increase in industrial activity should produce a considerable effect on output growth of the steel industry. Given the demand elasticity of industrial production of 0.7993 (see Table 1), the $3.77 \%$ increase in industrial

\footnotetext{
22 Most previous studies that examine the factors affecting productivity growth have employed a regression framework (see Mansfield, 1980; Crandall, 1980b; Link, 1982). To see how the regression framework gives biased results, the following OLS regression is run for 1957-1976 ( $t$ values in parentheses):

$\Delta \ln \mathrm{TFP}=0.0088+0.7094 \Delta \ln \mathrm{Y}+0.0793 \Delta \ln \mathrm{A}+0.1900 \Delta \ln \mathrm{R}-0.1188 \Delta \ln \mathrm{T}$ $\begin{array}{llll}(1.4747) 22.2579) \quad(6.6941) & (6.1804) \quad(-5.7452)\end{array}$

This suggests that increases in output, pollution abatement, and R\&D have positive effects, but an increase in technical change has a negative effect on TFP growth, a result that is incompatible with this study's decomposition analysis.
}

production in 1957-76 increased steel demand by $3.01 \%$ per year. It thus appears that high industrial activity has tended to offset the large negative effect induced by increases in domestic steel price in this period.

Looking at four subperiods, from 1957 to 1961 output grew, on average, at a negative rate of $3.25 \%$ a year. This negative output growth is mainly accounted for by a $2.72 \%$ increase in the domestic steel price, a $3.67 \%$ decrease in the import price of steel, and a $1.75 \%$ increase in industrial production. In this period, labor cost in the steel industry rose rather sharply because of the strike in 1959 , contributing to higher steel prices, and the economy was mired in the recession of 1958, which slowed industrial production. Further, a reduction in the import price of steel caused a reduction in domestic demand for steel. As the import price of steel declined relative to the domestic price, there was a substitution of imported steel for domestic steel, leading to a decrease in output growth in this period. A decrease in the import price of steel reflects low Japanese steel price as well as changes in the exchange rate between U.S. and other countries. The period 1957-62 is largely characterized by high import pressure, which contributed to a negative output growth. From 1962 to 1966 , output rebounded from a negative growth rate of the earlier period. The increase in the domestic price of steel slowed down considerably, and the decrease in the import price also slowed down. Moreover, there was a sharp increase in industrial production. All of these contributed to a relatively high growth of steel output in this period. From 1967 to 1971 , the steel industry appears to have the recurrent problem experienced in the 1957-61 period in terms of output growth; that is, high domestic steel prices, reflecting high wages and inappropriate pricing policies, largely contributed to negative output growth in this period.

The period from 1972 to 1976 is perhaps the most interesting. In this period, output growth rebounded to a small rate of $1.01 \%$ per year. However, the forces inducing this output growth are markedly different from those of the 1962-66 period. There were measurable increases in the domestic price of steel, which largely reflected OPEC-induced energy price increases. Steel wages also rose sharply in this period. Moreover, higher pollution abatement costs in this period would have contributed to a higher steel price. On the other hand, the import price of steel increased markedly in this 
Table 7. Decomposition of the Scale Effect in TFP Growth (Average Annual Percentage Rates of Change ${ }^{\text {a). }}$

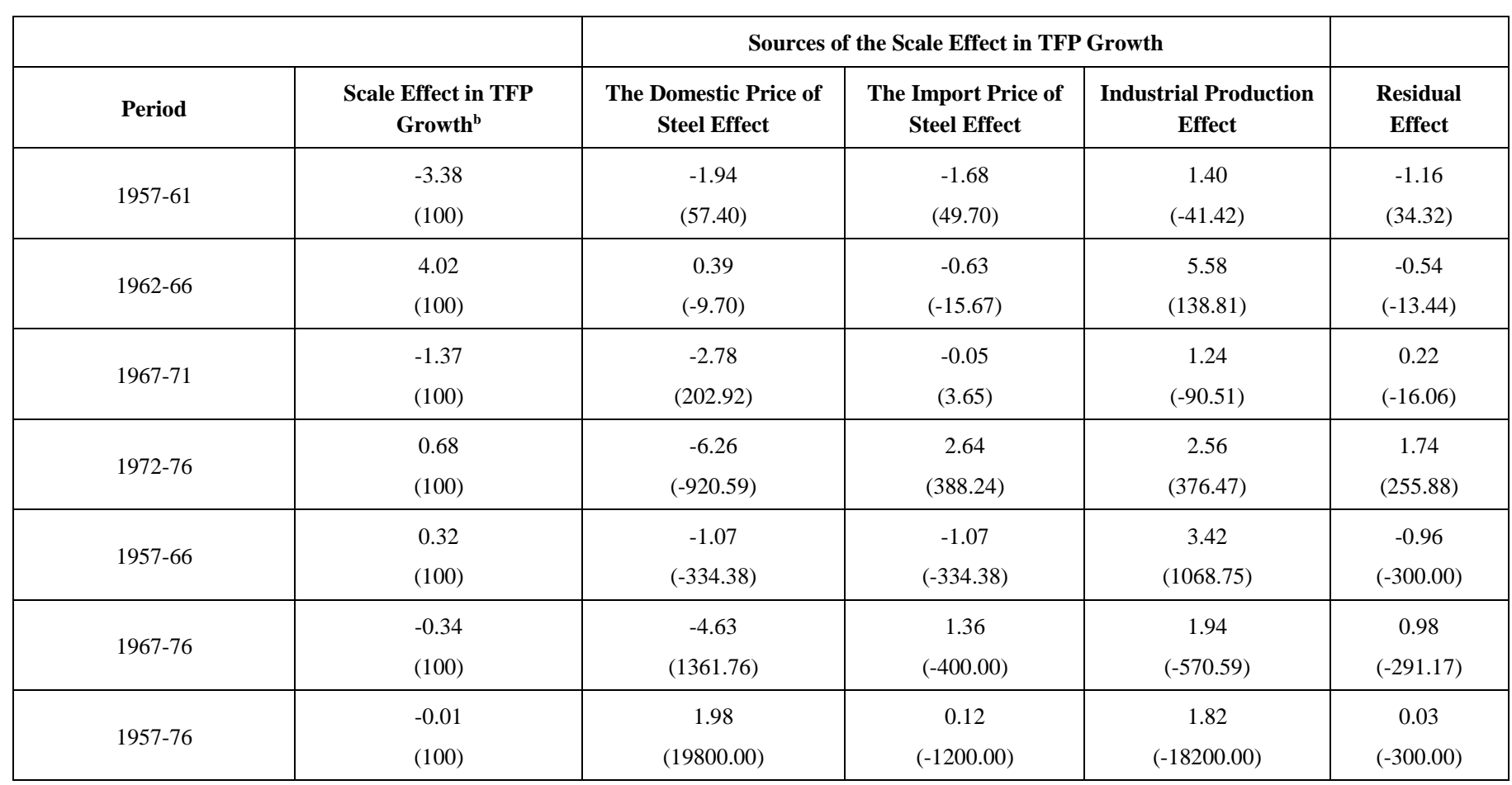

a The numbers in parentheses refer to percentage contributions of the components of the scale effect in TFP growth.

${ }^{\mathrm{b}}$ The sum of the domestic and import prices of steel, industrial production, and residual effects.

period, largely due to the Voluntary Restraints Agreements (VRAs) on imports (Crandall, 1981a). The increase in the import price of steel in this period had a positive effect on output growth, reflecting a "reverse" substitution of domestic steel for imported steel as the import steel price rose. While there was a rather large growth in industrial production, high domestic steel price appears to have swamped the positive demand effects triggered by industrial production and a high import price of steel in this period.

Table 7 summarizes the contribution of demand variables to productivity growth. The required demand elasticities are taken from Table 1 and the growth rates of demand variables are taken from Table 6. As can be seen there, the rise in the domestic price of steel over time was a drag on productivity growth in the steel industry. During the whole sample period, the domestic price effect decreased TFP growth by 1.98 percentage points. The import price effect in general had a positive contribution to productivity growth, increasing TFP growth by 0.12 percentage points in the $1957-76$ period. However, this result is rather misleading. From 1957-61 to 1967-71, the import price effect had a negative effect on productivity growth. In contrast, it had a positive effect on TFP growth in the $1972-77$ period. ${ }^{23}$ This positive effect on productivity growth comes from the fact that the import price of steel increased considerably in the 1972-76 period (see Table 6), causing a substitution of domestic steel for imported steel. While the domestic price effect had a strong nega-

${ }^{23}$ Grossman (1986) analyzed the effect of imported steel on domestic employment and found that an increase in the import price of steel had increased the demand for labor. The positive relation between the import price of steel and productivity growth is consistent with Grossman's finding. tive effect on productivity growth, industrial production has had a markedly positive effect on productivity growth, increasing TFP growth by 1.82 percentage points in the $1957-$ 76 period. The industrial production effect was strong enough to mitigate the negative contribution of the domestic price effect. Residual factors have had a small effect on productivity growth, accounting for a 0.03 percentage point increase in TFP growth in the 1957-76 period.

\section{SUMMARY AND CONCLUSION}

This study has described and analyzed productivity growth in the U.S. steel industry in the early period, with particular reference to the effects of pollution control. The steel industry had suffered from a sharp decline in productivity growth in the 1957-76 period. Changes in productivity growth are decomposed into the components attributable to scale effects, pollution control, R\&D stock, and technical change by allowing for markup behavior, and we have found the following contributing explanations for the steel industry's productivity problem:

- Despite pervasive economies of scale experienced by the steel industry, scale economies have not played a key role as a contributing factor to TFP growth over the years. The principal cause of the productivity problem in the steel industry was low or negative output growth stemming from sluggish demand. As a result, the steel industry operated with considerable excess capacity with consequent productivity retardation. Substantial price increases in domestic steel resulting from high wages and inappropriate pricing policies were largely responsible for low output growth. Strong industrial activity 
played a role in mitigating the negative steel price effect on productivity growth. Steel imports have not always had a detrimental impact on productivity growth. While steel imports had a negative effect in the early period, they had a positive effect on productivity growth in the latter period. In the latter period, there were marked increases in the import price of steel, leading to higher demand for domestic steel, which in turn yielded a productivity improvement.

- Pollution control was not an entirely detrimental influence on productivity growth. Pollution control had a dampening effect on productivity growth in the early period. However, compliance with increasingly stringent pollution standards in the latter period appears to have enticed and forced the steel industry to be more efficient in the use of inputs and have provided an added incentive to adopt the BOF technology, which yielded an acceleration of productivity growth. This finding is in marked contrast to those of previous studies.

- There is evidence that $R \& D$ funds were diverted to pollution control expenditures, and R\&D stock was not productive in the steel industry. This, coupled with the reduced rate of $R \& D$ stock accumulation, has in general led to reduced productivity growth, a result that is at odds with previous findings.

- There was substantial adoption of a new (BOF) technology in the early period. However, over the years there was technical retardation and considerable slowness in the adoption rate, which resulted in low productivity growth.

While the main focus of this paper has been on examining the link between pollution control and productivity growth, an important feature of the model is an explicit allowance for technical change and its effect on productivity growth in the U.S. steel industry. We used an early data set and examined the effect of the BOF technology on steelmaking subsequent to its introduction in the mid 1950's in the U.S. steel industry. This technology has been the dominant technology employed in integrated steel mills in the U.S. over the years, but there has been a gradual increase in steel production or shipment by mini-mills since the mid 1980's (see CollardWexler and De Loecker, 2015, Figure 1). Mini-mill steel plants are identified primarily by the use of an electric arc furnace to produce steel. While there are many explanations for the decline in integrated steel mills in the U.S., the failure to adopt improvements in steelmaking technology has often been identified as one of the central causes of the decline (see Lieberman and Johnson, 1999). Our finding showed that there was slowness in the BOF adoption rate in the later period that led to low productivity growth, which might have played a role in this decline.

Collard-Wexler and De Loecker (2015) investigate the productivity impact of mini-mills in the U.S. steel industry, using plant-level data between 1963 and 2002. There was a sharp increase in productivity in the steel industry during this period. They found that while this sharp increase in the in- dustry's productivity was largely due to an increase in productivity by integrated mills, mini-mills also played a significant role (see their Tables $\mathbf{7}$ and 8). This is as expected, and our results using earlier data also showed that the major driver of productivity in 1957-75 was the adoption of the BOF technology employed in integrated mills (see Table 5).

In 1957-75, the portion of steel production or employment by mini-mills was very small relative to that by integrated mills (see Collard-Wexler and De Loecker, 2015, Fig. 1). However, Collard-Wexler and De Loecker's (2015) analysis is limited to address many issues examined in this study. They do not provide information about the movement of productivity over time (see also Berman and Bui, 2001, for oil refineries). This information is more important to understand how productivity changed during their study period. We found that while there was a sharp increase in productivity in 1957-75, there was a sharp decline in productivity growth during this period. More importantly, they do not explore the link between pollution control and productivity growth with allowance for $\mathrm{R} \& \mathrm{D}$.

The U.S. steel industry is still suffering from sluggish demand from dwindling steel consumption, resulting in overproduction of steel. It may be noted, however, that both the inputs used in steelmaking and the products remain remarkably stable over the years (Collard-Wexler and De Loecker, 2015). Since productivity growth measures the relationship between output and inputs over time, this suggests that although we used an early data set for the U.S. steel industry, our findings can be still relevant to examine the issues facing the industry with respect to productivity growth. We hope that our findings will enable a better understanding of the nature and causes of the productivity problem and provide ways to improve productivity in the steel industry. In particular, given that low demand is the major cause of the productivity problem facing the U.S. steel industry, stimulating demand is the paramount task that the industry must undertake to raise productivity (see also Lieberman and Johnson, 1999). Reconsideration of the industry's traditional pricing policies seems particularly germane. In closing, we believe that the finding that pollution control can provide a positive inducement to productivity growth is revealing and merits attention. We do not, however, suggest or advocate that stricter pollution standards are necessary to improve productivity growth. Rather, it is suggested that researchers and policymakers heed this issue more closely instead of blindly accepting the negative view of pollution control on productivity growth.

\section{DATA APPENDIX}

The data used in this study are for the U.S. steel industry on an annual basis from 1956 to 1976 . They come from various sources from which variables are constructed. There are always acute data problems and the construction of variables is in no way perfect, but it is hoped that the constructed data set serves the purpose well.

The output of steel (Y) is raw steel measured in thousands of tons, which is taken from the Federal Trade Commission (FTC)'s Staff Report on the United States Steel Industry and its International Rivals. Pollution abatement (A) is measured 
by the steel industry's pollution control expenditures divided by the consumer price index. Pollution control expenditures are reported in the American Iron and Steel Institute (AISI)'s Annual Statistical Report for each year from 1965 to 1976. But from 1956 to 1964 the AISI Report only an aggregate sum for pollution expenditures. Thus allocation of pollution expenditures over this period on the basis of the steel industry's total sales was necessary. We summed annual sales from 1956 to 1964 to obtain total sales. Then each year's sales were taken as a percentage of total sales. This percentage for each year for the 1956-64 period was multiplied by total pollution expenditures over the 1956-64 period in order to arrive at annual pollution expenditures for this period.

Most of input data come from the FTC's Staff Report, with the exception of capital. The price of labor $\left(W_{L}\right)$ is defined as the wage rate per hour. The price of energy $\left(W_{E}\right)$ is a Divisia index which is comprised of the prices of fuel, electric power, and natural gas. The price of materials $\left(W_{M}\right)$ is represented by a Divisia index composed of the prices of coking and non-coking coal, iron ore, and scrap. The price of capital service $\left(W_{K}\right)$ is estimated with a well-established procedure. The cost of capital is first calculated as current-dollar value added minus current-dollar labor costs. The estimated capital cost is then divided by the gross book value of assets deflated by the producer durable price index to obtain the price of capital. The data are obtained from the Census of Manufacturers. Total cost $(\mathrm{C})$ is the sum of expenditures on capital, labor, energy, and materials. The cost share of each input $\left(S_{i}\right.$ for $i=K, L, E, M)$ is then obtained by dividing the expenditure of each input by total cost.

Total revenue (pY) is obtained from the AISI's Report. The price of steel (p) is the price of U.S. steel obtained from the AISI's Report divided by the manufacturers' producer price index given in the Handbook of Labor Statistics, U.S. Department of Labor. The import price of steel $\left(P_{\text {import }}\right)$ is the price of Japanese steel divided by the aggregate price index for all manufacturing and then multiplied by the U.S. - Japan exchange rate. The price of Japanese steel is obtained from the AISI's Report, the producer price index comes from the Handbook of Labor Statistics, U.S. Department of Labor, and the U.S.-Japan exchange rate comes from the International Monetary Fund's International Financial Statistics. The real industrial activity (V) is the Federal Reserve Board's index of industrial production, taken from the Federal Reserve Bulletin.

R\&D expenditures for the steel industry are reported in the National Science Foundation's Research and Development in Industry. From these expenditures the R\&D stock $(R)$ is created by deflating $\mathrm{R} \& \mathrm{D}$ expenditures by the consumer price index taken from the Council of Economic Advisers' Economic Report to the President and then using standard perpetual inventory methods that determine each year's net change in the stock by allowing for new investment and for depreciation (see Nadiri and Schankerman, 1980b). The measure of technical change (T) that took place in the steel industry is the BOF adoption rate given by the percentage of steel output made with the BOF process, which is obtained from the AISI's Report.

\section{CONFLICT OF INTEREST STATEMENT}

The authors declare that they have no conflict of interest.

\section{ACKNOWLEDGEMENT}

I would like to dedicate this paper to the memory of my former colleague Roy Howsen for friendship and early collaboration.

\section{REFERENCES}

Aiken, Deborah Vaughn and Carl A. Pasurka Jr., "Adjusting the Measurement of US Manufacturing Productivity for Air Pollution Emissions Control," Resource and Energy Economics 25 (2003), 329 351 .

American Iron and Steel Institute, Annual Statistical Report, Washington, D.C., various issues.

Barbera, Anthony J. and Virginia D. McConnell, "Effects of Pollution Control on Industry Productivity: A Factor Demand Approach," Journal of Industrial Economics 35 (Deceber 1986), 161-172.

Baumol, William J., John C. Panzar, and Robert D. Willig, Contestable Markets and the Theory of Industry Structure, New York: Harcourt Brace Jovanovich, 1982.

Berman, Eli and Linda T. M. Bui. "Environmental Regulation and Productivity: Evidence from Oil Refineries." Review of Economics and Statistics 83 (August 2001), 398-410.

Bresnahan, Timothy F. and Dennis A. Yao, "The Nonpecuniary Costs of Automobile Emissions Standards," Rand Journal of Economics 16 (Winter 1985), 437-455.

Chambers, Robert G., Applied Production Analysis. New York: Cambridge University Press, 1988.

Christainsen, Gregory B. and Robert H. Haveman, "The Contribution of Environmental Regulations to the Slowdown in Productivity Growth," Journal of Environmental Economics and Management 8 (December 1981), 381-390.

Christensen, Laurits. R., Dale W. Jorgenson, and Lawrence J. Lau, "Transcendental Logarithmic Production Frontiers," Review of Economics and Statistics 55 (February 1973), 28-45.

Collard-Wexler, Allan and Jan De Loecker, "Reallocation and Technology: Evidence from the US Steel Industry," American Economic Review 105(1), 2015, 131-171.

Conrad, Klaus and Catherine J. Morrison, "The Impact of Pollution Abatement Investment on Productivity Change: An Empirical Comparison of the U.S., Germany, and Canada," Southern Economic Journal 55 (January 1989), 684-698.

Council of Economic Advisers, Economic Report of the President, Washington, D.C.: Government Printing Office, various issues.

Crandall, Robert W., The U.S. Steel Industry in Recurrent Crisis, Washington, D.C.: The Brookings Institution, 1981a.

Crandall, Robert W., "Pollution Controls and Productivity Growth in Basic Industries," in Thomas G. Cowing and Rodney E. Stevenson (eds.), Productivity Measurement in Regulated Industries, New York: Academic Press, 1981b, 348-368.

Denison, Edward F., "Pollution Abatement Programs: Estimation of Their Effect upon Output Per Unit of Input: 1975-1978." Survey of Current Business 59 (August 1979), Part I, 58-59.

Diewert, W. Erwin, "The Theory of Total Factor Productivity Measurement in Regulated Industries,"in Thomas G. Cowing and Rodney E. Stevenson (eds.), Productivity Measurement in Regulated Industries, New York: Academic Press, 17-44.

Diewert ,W. Erwin and Kevin J. Fox, "On the Estimation of Returns to Scale, Technical Progress and Monopolistic Markups," Journal of Econometrics 145 (July 2008) 174-193.

Eads, George, "Regulation and Technical Change: Some Largely Unexplained Influences," American Economic Review, Papers and Proceedings 70 (May 1980), 50- 54.

Färe, Rolf, Shawna Grosskopf, C.A. K. Lovell, and Carl Pasurka, "Multilateral Productivity Comparisons When Some Outputs are Undesirable: A Nonparametric Approach," Review of Economics and Statistics 71 (February 1989), 90-98. 
Federal Reserve Board, Federal Reserve Bulletin, Washington, D.C., various issues.

Federal Trade Commission, Staff Report on the United States Steel Industry and its International Rivals: Trends and Factors Determining International Competitiveness Bureau of Economics, November 1977.

Gollop, Frank M. and Dale W. Jorgenson, "U.S. Productivity Growth by Industry, 1947 -73," in John W. Kendrick and Beatrice N. Vaccara (eds.), New Developments in Productivity Measurements and Analysis, Chicago: University of Chicago Press, 1980, 17-124.

Gollop, Frank M. and Mark J. Roberts, "Environmental Regulations and Productivity Growth: The Case of Fossil-Fueled Electric Power Generation," Journal of Political Economy 91 (August 1983), 654674.

Griliches, Zvi, "Productivity Puzzles and R\&D: Another Nonexplanation," Journal of Economic Perspectives 2 (Fall 1988), 9-21.

Grossman, Gene M., "Imports As a Cause of Injury: The Case of the U.S. Steel Industry," Journal of International Economics 20 (May 1986), 201-223.

Hanoch, Giora, "The Elasticity of Scale and the Shape of the Average Costs," American Economic Review 65 (June 1975), 492-497.

International Monetary Fund, International Financial Statistics, Washington, D.C., 1985.

Karlson, Steven H., "Modelling Location and Production: An Application to U.S. Fully -Integrated Steel Plants," Review of Economics and Statistics 64 (February 1983), $41-50$.

Kim, H. Youn, "Economies of Scale in Multiproduct Firms: An empirical Analysis," Economica 54 (May 1987), 185-206.

Kopp, Raymond J. and V. Kerry Smith, "Productivity Measurement and Environmental Regulation: An Engineering-Econometric Analysis," in Thomas G. Cowing and Rodney E. Stevenson (eds.), Productivity Measurement in Regulated Industries, New York: Academic Press, 1981, 249-281.

Lieberman, Marvin B. and Douglas R. Johnson, "Comparative Productivity of Japanese and U.S. Steel Producers, 1958-1993," Japan and the World Economy 11 (1999), 1-27.

Link, Albert N., "Productivity Growth, Environmental Regulations and the Composition of R\&D," Bell Journal of Economics 13 (Autumn 1982), 548-554.

Lynn, Leonard, "New Data on the Diffusion of the Basic Oxygen Furnace in the U.S. and Japan," Journal of Industrial Economics 30 (December 1981), 123-135.
Mansfield, Edwin, "Basic Research and Productivity Increase in Manufacturing," American Economic Review 70 (December 1980), 863873.

Nadiri, M. Ishaq and Mark A. Schankerman, "Technical Change, Returns to Scale, and the Productivity Slowdown," American Economic Review, Papers and Proceedings 71 (May 1981a), 314-319.

Nadiri, M. Ishaq and Mark A. Schankerman, "The Structure of Production, Technological Change, and the Rate of Growth of Total Factor Productivity in the U.S. Bell System," in Thomas G. Cowing and Rodney E. Stevenson (eds.), Productivity Measurement in Regulated Industries, New York: Academic Press, 1981b, 219-247.

National Science Foundation, Research and Development in Industry, Washington, D.C.: Government Printing Office, various issues.

Oster, Sharon, "The Diffusion of Innovation among Steel Firms: The Basic Oxygen Furnace." Bell Journal of Economics 13 (Spring 1982), 45-56

Pittman, Russel W., "Issues in Pollution Control: Interplant Cost Differences and Economies of Scale," Land Economics 57 (February 1981), 1-17.

Scherer, F.M., "Inter-Industry Technology Flows and Productivity Growth," Review of Economics and Statistics 64 (November 1982), 627-634.

Smith, J. B. and W. A. Sims, "The Impact of Pollution Charges on Productivity Growth in Canadian Brewing," Rand Journal of Economics 16 (Autumn 1985), 410-423.

Sumall, James B. Jr., "Diffusion of the Basic Oxygen Furnace in the U.S. Steel Industry," Journal of Industrial Economics 30 (June 1982), 421-437.

Syverson, Chad, "What Determines Productivity?" Journal of Economic Literature 49 ( 2011), 326-365.

Teleckyj, Nestor E., "What Do R \& D Numbers Tell Us About Technological Change?," American Economic Review, Papers and Proceedings 70 (May 1980), 55-61.

Thorn, Richard S., "Steel Imports, Labor Productivity, and Cost Competitiveness," Western Economic Journal 6 (December 1968), 375-384

U.S. Department of Commerce, Bureau of Census, Census of Manufacturers, Washington, D.C., various issues.

U.S. Department of Labor, Handbook of Labor Statistics, Washington, D.C., various issues.

Zivin, Joshua Graff and Matthew Neidell, "The Impact of Pollution on Worker Productivity," American Economic Review 102 (December 2012), 3652-3673.

Copyright (C) 2021- All Rights Reserved

This is an open-access article. 